NOTE

\title{
Digestion of diatoms by planktonic copepods and doliolids
}

\author{
G.-A. Paffenhöfer ${ }^{1, *}$, M. Köster ${ }^{2}$ \\ ${ }^{1}$ Skidaway Institute of Oceanography, 10 Ocean Science Circle, Savannah, Georgia 31411, USA \\ ${ }^{2}$ Institut für Ökologie der Ernst-Moritz-Arndt Universität Greifswald, 18565 Kloster/Hiddensee, Germany
}

\begin{abstract}
The goal of our studies was to quantify the digestive performance of a calanoid copepod in comparison to a commonly occurring pelagic tunicate. A comparison of the carbon and nitrogen content of quantitatively recovered fecal pellets with ingested amounts revealed that the large calanoid Eucalanus hyalinus digested the diatoms Thalassiosira weissflogii and Rhizosolenia alata significantly better than the doliolid Dolioletta gegenbauri did. This was attributed to the copepods' ability to crush the diatom cells after ingestion, while the doliolids caused minimal physical damage to the diatom cells. As for $D$. gegenbauri, it digested the large diatom $R$. alata far better than the small diatom $T$. weissflogii. The pellets from the latter contained nearly $50 \%$ of the ingested carbon and nitrogen. These findings are supported by visual observations. The results imply that doliolids are not able to utilize diatoms as efficiently as calanoid copepods, and will most likely rely more on softwalled food particles such as flagellates. These findings also imply that a considerable percentage of particulate organic matter ingested by doliolids, in water masses dominated by diatoms, could become available to the benthic communities of continental shelves since the doliolid pellets sink quite rapidly.
\end{abstract}

KEY WORDS: Digestion $\cdot$ Diatoms $\cdot$ Copepods $\cdot$ Doliolids

\section{INTRODUCTION}

After copepods, pelagic tunicates are thought to be the most abundant metazooplankton. Although copepods usually outnumber tunicates (even in terms of biomass), high concentrations not only of Appendicularia but also of Thaliacea have been observed in neritic subtropical and tropical waters (Belousov et al. 1966, Heron 1972, De Decker 1973, Monteiro et al. 1975, Binet 1976, Madhupratap et al. 1980, Esnal \& Simone 1982, LeBorgne 1983, Pieper \& Holliday 1984, Deibel 1985, Koga 1986, Paffenhöfer \& Lee 1987a, He et al. 1988, Paffenhöfer et al. 1995). Among planktonic copepods, calanoids are known to select food particles via chemo- and/or mechanoperception, while doliolids are not known to be selective. The food spectrum of the latter ranges from around $2 \mu \mathrm{m}$ cell width/diameter to $>30 \mu \mathrm{m}$ (Deibel 1985) and increases with the size of the respective zooid. In contrast, calanoids gather larger food particles after having perceived them, while they passively gather smaller, non-perceived particles (Price et al. 1983), which results in much higher clearance rates of large compared to small particles (Price \& Paffenhöfer 1985). This implies that a doliolid will most likely ingest particles of 4 and $20 \mu \mathrm{m}$ diameter at similar rates, whereas a calanoid copepod will ingest the latter particle at a much higher rate than the former one.

While copepods crush nearly all ingested food particles, our preliminary observations revealed that doliolids either do not, or only slightly physically damage ingested diatoms. Therefore, we wondered to 
what extent doliolids could utilize diatoms, which are abundant in upwellings and on continental shelves. During the summer of 1978, small (Thalassiosira subtilis) and large diatoms (Rhizosolenia alata) were abundant in shelf break upwellings off the southeastern USA. The same was true for large diatoms (Guinardia flaccida, Stephanopyxis turris) in the summer of 1981 (Paffenhöfer 1983, Paffenhöfer \& Lee 1987b). We asked how well doliolids can utilize small and large diatoms occurring abundantly in their natural environment compared to calanoid copepods. Since the extent of assimilation could not be quantified accurately (see Møller et al. 2003, Thor et al. 2003), we decided to express utilization as digestion efficiency, i.e. as the difference between ingested and defecated carbon and nitrogen in relation to the ingested carbon and nitrogen, respectively.

\section{MATERIALS AND METHODS}

Experiments were conducted at $20^{\circ} \mathrm{C}$ with adult females of the large shelf-break/open ocean calanoid copepod Eucalanus hyalinus (Cowles et al. 1987, Paffenhöfer \& Mazzocchi 2003) and with gonozooids of the doliolid Dolioletta gegenbauri, which is usually found in neritic subtropical waters (references in Paffenhöfer et al. 1995). The main food organisms were the small diatom Thalassiosira weissflogii $(\sim 7 \mu \mathrm{m}$ cell width, $185 \mu \mathrm{g} \mathrm{C}$ and $33.6 \mu \mathrm{g} \mathrm{N} \mathrm{mm}{ }^{-3}$ of cell volume) and the large diatom Rhizosolenia alata (32 $\mu \mathrm{m}$ width, $13.55 \mu \mathrm{g} \mathrm{C}$ and $2.25 \mu \mathrm{g} \mathrm{N} \mathrm{mm}{ }^{-3}$ of cell volume). In the experiments with $E$. hyalinus and $D$. gegenbauri, small amounts of the dinoflagellate Gymnodinium nelsoni $(35 \mu \mathrm{m}$ width, $130 \mu \mathrm{g} \mathrm{C}$ and $21.7 \mu \mathrm{g} \mathrm{N} \mathrm{mm}^{-3}$ of cell volume) and of the flagellate Isochrysis galbana (4.5 $\mu \mathrm{m}$ width, $200 \mu \mathrm{g} \mathrm{C}$ and $36.3 \mu \mathrm{g}$ $\mathrm{Nmm}^{-3}$ of cell volume) or of G. nelsoni were added, respectively. These additions were intended to coarsely simulate the natural food environment by offering a flagellated taxon, which would on average contribute 5 to $10 \%$ of the total food intake.

The females of Eucalanus hyalinus and the gonozooids of Dolioletta gegenbauri originated from assemblages which had been reared under controlled food conditions at $20^{\circ} \mathrm{C}$ with various phytoplankton species at average concentrations ranging from about 30 to $70 \mu \mathrm{g} \mathrm{Cl}^{-1}$. Prior to the experiments, the respective animals had been acclimated for 24 to $48 \mathrm{~h}$ to the experimental conditions. The experiments with E. hyalinus were conducted in $4 \mathrm{l}$ beakers with 6 females in $3500 \mathrm{ml}$ using a tumbler at $0.5 \mathrm{rpm}$ (Paffenhöfer 1970). This tumbler consisted of a beaker or jar angled at about $20^{\circ}$ and moved continuously in a circle (see Fig. 1 in Paffenhöfer 1970). This method keeps many diatom species and flagellates in suspension, while the fecal pellets, which are usually denser than the cells, sink to the bottom. This limits the reingestion of pellets by the copepods, which almost always remain suspended in the large beaker or jar. The average body weight $( \pm 1 \mathrm{SE}$ ) of an $E$. hyalinus female was $172 \pm 17 \mu \mathrm{g} \mathrm{C}$ and $45 \pm 5 \mu \mathrm{g} \mathrm{N}$, and their prosome length ranged from 4.5 to $5.0 \mathrm{~mm}$. The experiments with the gonozooids of $D$. gegenbauri were conducted with 3 zooids per $1900 \mathrm{ml}$ screw cap bottle on a plankton wheel rotating at $0.3 \mathrm{rpm}$. This method was used because doliolids could not have tolerated the contact with air-water interfaces that would have occurred in a tumbling beaker. Judging from the type and color of pellets collected, ingestion of sizable fecal pellets appeared not to occur. Earlier observations revealed that pellets that had been ingested by the doliolids were much darker than pellets originating from the ingestion of diatoms. The zooids ranged from 7 to $9.5 \mathrm{~mm}$ in length, and had body weights ranging from 114 to $215 \mu \mathrm{g} \mathrm{C}$ and 28 to $52 \mu \mathrm{g} \mathrm{N}$. For each experiment, 1 to 2 control bottles (volume $=960 \mathrm{ml}$ ) were run to determine algal growth rates. An inverted microscope was used to quantify all the experimental and control concentrations with Rhizosolenia alata and Gymnodinium nelsoni, as well as in the E. hyalinus experiments with $T$. weissflogii and G. nelsoni, while a Coulter Multisizer (having been previously compared with inverted microscope counts) was used for the $D$. gegenbauri experiments with $T$. weissflogii and Isochrysis galbana. Feeding and pellet production experiments lasted between 8 and $25 \mathrm{~h}$ at $20^{\circ} \mathrm{C}$.

At the end of each experiment, the pellets produced by the experimental animals were immediately collected with a small pipette and then gently released into small dishes where they accumulated on the bottom. The pellets of the Eucalanus hyalinus females ranged from 0.09 to $0.14 \mathrm{~mm}$ in width and from 1.0 to $1.5 \mathrm{~mm}$ in length, while those of the gonozooids of Dolioletta gegenbauri were an aggregation of loosely packed cells and ranged from about 0.4 to $1.0 \mathrm{~mm}$ in diameter. Some of the copepod pellets had been broken by the females but were seemingly not ingested as judged from their color. The doliolids' pellets had to be transferred to the dishes rather gently to prevent them from coming apart. Losses were estimated to be less than $5 \%$. Hardly any smaller doliolid pellets were found at the end of the experiments, indicating that the water motion in the experimental jars was indeed gentle. Pellet samples for the analyses of carbon and nitrogen content were dried at $60^{\circ} \mathrm{C}$ for $24 \mathrm{~h}$ and combusted at $970^{\circ} \mathrm{C}$ in an elemental CHN analyzer (Heraeus vario-el, Köster et al. 1997).

Since we could not determine that all the material difference between ingestion and defecation had been assimilated by the respective feeder (e.g. Møller et al. 
2003, Thor et al. 2003), we chose to express this difference as digestion efficiency: $\mathrm{DE}=(I-F) / I \times 100$, with $I$ being the ingested and $F$ the defecated amount. It is possible that all the digested material could be assimilated.

From each type of experiment, some pellets were preserved in formaldehyde ( $2 \%$ final concentration) to visually estimate the degree of degradation of diatom cells due to digestion. This was accomplished from micrographs taken with a Vosskühler digital camera connected to an epifluorescence microscope (Zeiss Axiophot).

\section{RESULTS AND DISCUSSION}

We offered a diet of small and large diatoms to copepods and doliolids at concentrations that occur in neritic waters and were not satiating. For comparative purposes, we attempted to have copepods and doliolids ingest similar amounts of diatom carbon and nitrogen per hour. The doliolids dictated the food concentrations chosen since Eucalanus hyalinus perceived the large diatom actively but rarely perceived the small one (Price \& Paffenhöfer 1986). In order to have fairly similar ingestion rates in terms of carbon and nitrogen for both diatom species, carbon concentrations of Thalassiosira weissflogii more than 4 times higher than those of Rhizosolenia alata were necessary (Table 1). The large Dolioletta gegenbauri gonozooids do not select food particles in the size range chosen here. The resulting average clearance rates of the gonozooids of both diatoms were similar and were close to that of the copepod females on $R$. alata, while the copepod's rates on T. weissflogii, for the reason given above, were far lower. Using average clearance rates and food concentrations, E. hyalinus ingested $59 \%$ of its body carbon daily when feeding on $T$. weissflogii, and $31.0 \%$ when feeding on $R$. alata, while $D$. gegenbauri ingested $93.9 \%$ of its body carbon when feeding on $T$. weissflogii and $52.5 \%$ when feeding on $R$. alata. The higher weight-specific ingestion rates when feeding on $T$. weissflogii are attributed to its concentration $\left(\mu \mathrm{g} \mathrm{C} \mathrm{l}^{-1}\right)$ being higher than that of $R$. alata for both zooplankton species, and to the respective clearance rates (Table 1). Based on previous observations, the aforementioned weight-specific ingestion values were not considered to be near satiating levels (Price \& Paffenhöfer 1986, Gibson \& Paffenhöfer 2000). Comparing the average ingestion rates as a percentage of body carbon, the ingestion rate of $D$. gegenbauri was $59 \%$ higher than that of $E$. hyalinus when feeding on T. weissflogii, and $70 \%$ higher when feeding on $R$. alata (Table 1 ). In the respective experiments, the ingested Gymnodinium nelsoni amounted to 5.9 and $5.6 \%$ of the total ingestion of $E$. hyalinus; Isochrysis galbana accounted for $9.4 \%$ (with T. weissflogii), and G. nelsoni $11.4 \%$ (with $R$. alata), respectively, for $D$. gegenbauri (Table 1), thus comprising only a small percentage of the total ingested carbon and nitrogen.

The pellets of Eucalanus hyalinus contained less than $8 \%$ of the carbon or nitrogen ingested, while those of Dolioletta gegenbauri amounted to nearly $50 \%$ of the ingested material when feeding on Thalassiosira weissflogii, and 19 and $27 \%$ of ingested nitrogen and carbon, respectively, when feeding on Rhizosolenia alata (Table 1). A Multiple Comparison test following the Kruskal-Wallis test (single factor analysis of variance by ranks, Conover 1984), comparing pellets as a percentage of ingestion, revealed the following significant sequence $(\mathrm{p}<0.05)$ : $D$. gegenbauri/T. weissflogii $>D$. gegenbauri/R. alata $>E$.

Table 1. Food concentrations, clearance and ingestion rates, and fecal pellet results of copepod and doliolid feeding experiments at $20^{\circ} \mathrm{C}$. $\mathrm{x}$ : mean; n: number of observations

\begin{tabular}{|c|c|c|c|c|c|c|c|}
\hline \multirow[t]{2}{*}{$\begin{array}{l}\text { Feeder and } \\
\text { food species }\end{array}$} & & \multirow{2}{*}{$\begin{array}{c}\text { Food } \\
\text { conc. } \\
\left(\mu \mathrm{C} \mathrm{C}^{-1}\right)\end{array}$} & \multirow{2}{*}{ 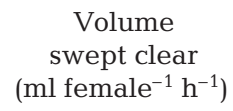 } & \multirow[t]{2}{*}{$\begin{array}{c}\text { Ingestion } \\
\left(\% \text { of body } \mathrm{C} \mathrm{h}^{-1}\right)\end{array}$} & \multicolumn{2}{|c|}{$\begin{array}{c}\text { Pellets } \\
\text { (\% of ingestion) }\end{array}$} & \multirow[t]{2}{*}{$\begin{array}{l}\text { Pellet } \\
\text { C:N }\end{array}$} \\
\hline & & & & & $\mathrm{C}$ & $\mathrm{N}$ & \\
\hline Eucalanus hyalinus & $\mathrm{x}$ & 298.8 & 13.88 & 2.46 & 6.7 & 5.5 & 6.7 \\
\hline \multirow[t]{2}{*}{ Thalassiosira weissflogii } & $\mathrm{n}$ & 10 & 10 & 10 & 5 & 5 & 5 \\
\hline & SE & \pm 16.3 & \pm 1.89 & \pm 0.38 & \pm 1.9 & \pm 1.2 & \pm 0.4 \\
\hline Eucalanus hyalinus & $\mathrm{x}$ & 64.8 & 42.2 & 1.29 & 7.7 & 7.4 & 6.4 \\
\hline \multirow{2}{*}{ Rhizosolenia alata } & $\mathrm{n}$ & 8 & 8 & 8 & 4 & 4 & 4 \\
\hline & SE & \pm 9.14 & \pm 5.4 & \pm 0.10 & \pm 0.3 & \pm 0.7 & \pm 0.8 \\
\hline Dolioletta gegenbauri & $\mathrm{x}$ & 124.1 & 40.8 & 3.91 & 49.4 & 48.6 & 5.7 \\
\hline \multirow[t]{2}{*}{ Thalassiosira weissflogii } & $\mathrm{n}$ & 8 & 8 & 8 & 5 & 6 & 6 \\
\hline & SE & \pm 18.8 & \pm 4.1 & \pm 0.48 & \pm 5.4 & \pm 5.0 & \pm 0.1 \\
\hline Dolioletta gegenbauri & $\mathrm{x}$ & 99.6 & 42.9 & 2.19 & 26.7 & 20.7 & 7.7 \\
\hline \multirow[t]{2}{*}{ Rhizosolenia alata } & $\mathrm{n}$ & 6 & 6 & 6 & 6 & 5 & 5 \\
\hline & SE & \pm 12.4 & \pm 7.0 & \pm 0.22 & \pm 2.5 & \pm 2.1 & \pm 0.3 \\
\hline
\end{tabular}


Table 2. Assimilation efficiency (\% of ingestion) of planktonic copepods and tunicates. C: carbon; N: nitrogen

\begin{tabular}{|c|c|c|c|c|c|}
\hline Species & $\begin{array}{c}\text { Food } \\
\text { species }\end{array}$ & $\begin{array}{c}\text { Food } \\
\text { conc. } \\
\left(\mu \mathrm{C} \mathrm{l}^{-1}\right)\end{array}$ & $\%$ & Range & Source \\
\hline Calanus helgolandicus & Natural particulate matter & & 80 & $79-91$ & Corner (1961) \\
\hline Calanus hyperboreus & $\begin{array}{c}\text { Thalassiosira fluviatilis } \\
\text { Skeletonema costatum } \\
\text { Rhizosolenia setigera } \\
\text { Dunaliella sp. }\end{array}$ & & $\begin{array}{l}67.3 \\
40.1 \\
56.8 \\
86.7\end{array}$ & $\begin{array}{l}36.7-87.9 \\
36.7-44.6 \\
18.8-73.3 \\
75.1-89.9\end{array}$ & Conover (1966) \\
\hline Calanus helgolandicus & Biddulphia sinensis & $29-290$ & $34.1 \mathrm{~N}$ & & Corner et al. (1972) \\
\hline Eucalanus hyalinus & $\begin{array}{c}\text { Thalassiosira weissflogii } \\
\text { Rhizosolenia alata }\end{array}$ & $\begin{array}{l}299 \\
65\end{array}$ & $\begin{array}{l}93.3 \mathrm{C} \\
95.1 \mathrm{~N} \\
92.3 \mathrm{C} \\
93.2 \mathrm{~N}\end{array}$ & $\begin{array}{l}86.7-97.2 \\
90.6-97.6 \\
91.3-92.9 \\
91.4-94.8\end{array}$ & This study \\
\hline Salpa fusifornius & Phaeodactylum tricornutum & & 32 & $28-39$ & Andersen (1986) \\
\hline Salpa fusifornis & Hymenomonas elongata & & 64 & $39-81$ & Andersen (1986) \\
\hline Dolioletta gegenbauri & $\begin{array}{c}\text { Thalassiosira weissflogii } \\
\text { Rhizosolenia alata }\end{array}$ & $\begin{array}{l}124 \\
100\end{array}$ & $\begin{array}{l}50.6 \mathrm{C} \\
54.3 \mathrm{~N} \\
73.3 \mathrm{C} \\
80.8 \mathrm{~N}\end{array}$ & $\begin{array}{r}27.5-67.2 \\
32.9-68.8 \\
66.7-80.4 \\
73.8-85.7\end{array}$ & This study \\
\hline
\end{tabular}

hyalinus/R. alata = E. hyalinus/T. weissflogii. The digestion efficiencies of $E$. hyalinus were unusually high when compared to earlier observations on the assimilation efficiency of planktonic copepods (Table 2); however, they were near the upper end of the ranges of the studies cited on Calanus hyperboreus (Conover 1966) and C. helgolandicus (Corner 1961). The digestion efficiency data obtained for $D$. gegenbauri were in the range of those obtained previously for calanoid copepod assimilation efficiencies when feeding on diatoms (Table 2). The only available assimilation data for thaliacea feeding on a small diatom revealed even lower values for Salpa fusiformis than found for D. gegenbauri digestion in our studies (Table 2, Andersen 1986), and appeared to confirm our results. Even among copepods, low assimilation efficiencies could occur (Table 2, Corner et al. 1972). The variability of assimilation efficiencies has been discussed repeatedly (e.g. Conover 1978), and should depend to a large extent on food type and feeder taxon. As an example of the upper extreme, the pteropod Clione limacina assimilated its prey, the pteropod Spiratella sp., with an efficiency of $99 \%$ (Conover \& Lalli 1974).

Our results on fecal pellet carbon and nitrogen content should be regarded as underestimates as earlier studies have demonstrated that pellets, after being produced by the respective copepod, released considerable amounts of dissolved organic carbon (DOC). For example, pellets produced by females of Calanus finmarchicus and C. glacialis released more than $20 \%$ of their carbon content as DOC during the first 60 min after being expelled (Møller et al. 2003); fecal pellets produced by Acartia tonsa lost significant amounts of their organic carbon over the $96 \mathrm{~h}$ period following their collection (Thor et al. 2003). Since both studies were conducted at food concentrations of $500 \mu \mathrm{g}$ of phytoplankton $\mathrm{C}^{-1}$ and higher, DOC release rates as high as those shown for Calanus spp. (Møller et al. 2003) could not be observed at the phytoplankton levels used to feed Eucalanus hyalinus and Dolioletta gegenbauri in the present study. Yet, the probability of underestimating the content of organic matter in pellets of E. hyalinus is high because pellets were collected within 8 to $25 \mathrm{~h}$ of the beginning of each experiment, i.e. up to $25 \mathrm{~h}$ after being expelled. Such losses of organic matter from the $D$. gegenbauri pellets were most likely limited because most of the cells were not physically damaged, and therefore not as efficiently digested as by the copepods.

Photographs of the pellets produced by Dolioletta gegenbauri (Fig. 1a-d) and Eucalanus hyalinus (Fig. 1e,f) support our findings on the digestive performance expressed as $\mathrm{C}$ and $\mathrm{N}$ quantifications. Densely packed E. hyalinus pellets reveal only crushed diatoms and a few spots of autofluorescence from a few undigested Thalassiosira weissflogii cells, i.e. hardly any chlorophyll is left (Fig. 1e,f), whereas pellets from $D$. gegenbauri show a loose aggregation of undamaged $T$. weissflogii cells and uncrushed Rhizosolenia alata cells (Fig. 1a,c). Here, the T. weissflogii pellet contains numerous red fluorescing cells, i.e. it contains chlorophyll (Fig. 1b), whereas the $R$. alata pellet shows hardly any red fluorescence (Fig. 1d). Observations by Pomeroy \& Deibel (1980) also revealed that small diatom cells (Thalassiosira subtilis) appeared undamaged in fecal material of $D$. gegenbauri, as shown by bright red fluorescence. 


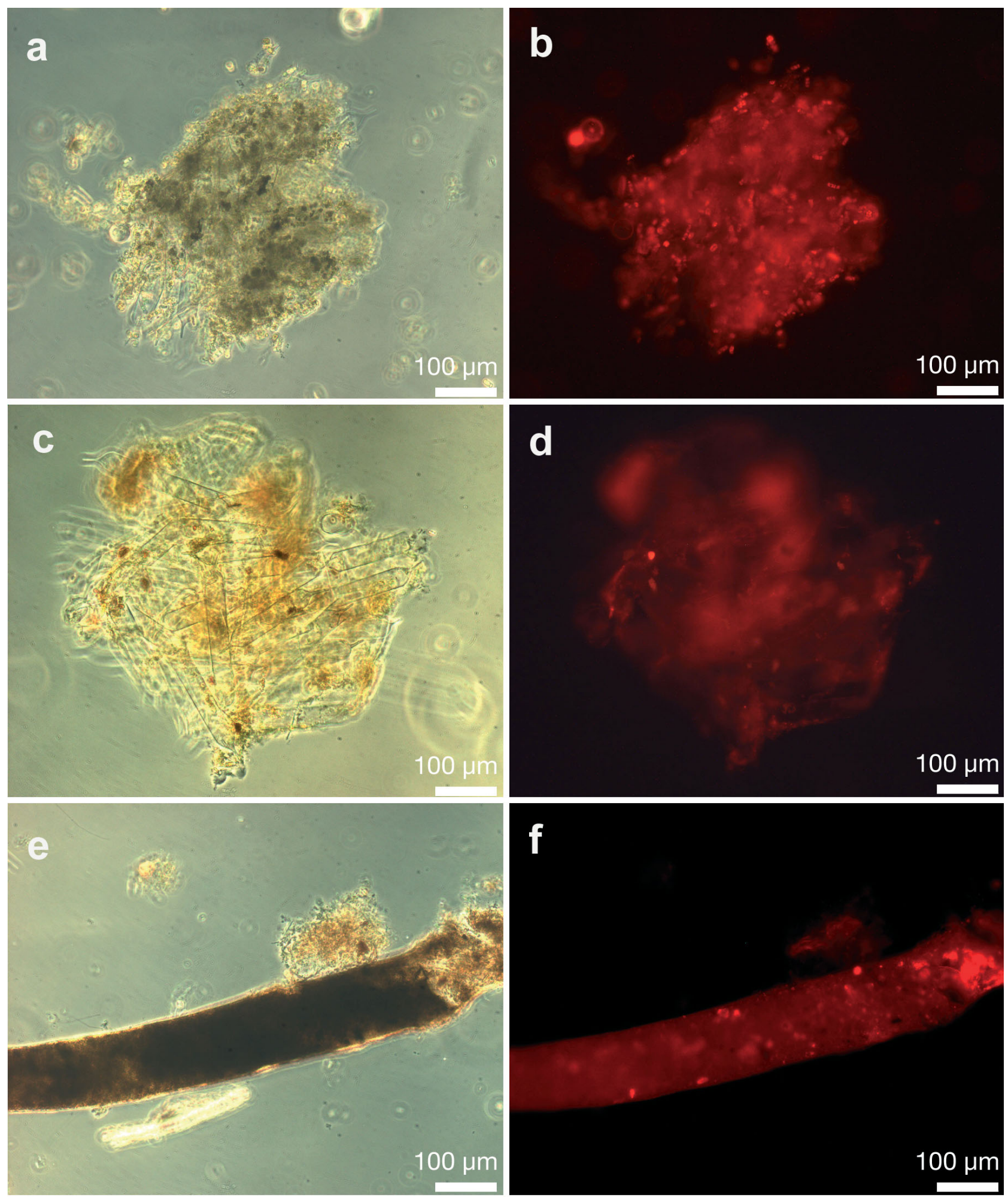

Fig. 1. Micrographs of fecal pellets of doliolids and copepods. (a), (c) and (e) were taken with phase contrast, while (b), (d) and (f) were taken at an excitation of 510 to $560 \mathrm{~nm}$ (dichroic mirror $560 \mathrm{~nm}$, emission 575 to $640 \mathrm{~nm}$ ) to detect free-living and digested microalgae via chlorophyll autofluorescence. $(\mathrm{a}, \mathrm{b})$ Fecal pellet of Dolioletta gegenbauri feeding on Thalassiosira weissflogii; (c,d) fecal pellet of D. gegenbauri feeding on Rhizosolenia alata; (e, f) fecal pellet of Eucalanus hyalinus feeding on T. weissflogii 
Table 3. C:N ratios of fecal pellets of planktonic copepods and tunicates

\begin{tabular}{|c|c|c|c|c|}
\hline Species & Food & $\begin{array}{l}\text { Food conc. } \\
\left(\mu \mathrm{C} \mathrm{Cl}^{-1}\right)\end{array}$ & $C: N$ & Source \\
\hline Eucalanus pileatus & Rhizosolenia alata & $80-120$ & 14.8 & $\begin{array}{l}\text { Paffenhöfer \& } \\
\text { Knowles (1979) }\end{array}$ \\
\hline $\begin{array}{l}\text { Temora longicornis } \\
\text { Pseudocalanus spp. }\end{array}$ & Thalassiosira weissflogii & $\begin{array}{l}250-19000 \\
\text { cells ml }{ }^{-1}\end{array}$ & $7.3-8.7$ & Morales (1987) \\
\hline Calanus pacificus & Thalassiosira weissflogii & 222 & $7.0-10.1$ & Cowie \& Hedges (1996) \\
\hline Eucalanus hyalinus & $\begin{array}{c}\text { Thalassiosira weissflogii } \\
\text { Rhizosolenia alata }\end{array}$ & $\begin{array}{c}299 \\
65\end{array}$ & $\begin{array}{l}6.7 \\
6.4\end{array}$ & This study \\
\hline $\begin{array}{l}\text { Salpa fusiformis } \\
\text { Pegea socia }\end{array}$ & Natural food & - & $5.4-6.2$ & Bruland \& Silver (1981) \\
\hline Salpa maxima & Natural food & - & 11.4 & Madin (1982) \\
\hline Salpa maxima & Natural food & - & $12.8-18.1$ & Caron et al. (1989) \\
\hline Pegea discaudata & & & $11.5-29.4$ & \\
\hline Cyclosalpa affinis & & & $16.1-23.9$ & \\
\hline \multirow[t]{2}{*}{ Dolioletta gegenbauri } & Thalassiosira weissflogii & 124 & 5.7 & This study \\
\hline & Rhizosolenia alata & 100 & 7.7 & \\
\hline
\end{tabular}

Our results imply that Dolioletta gegenbauri would not grow optimally if small diatoms were abundant but would obtain a considerable amount of energy from larger diatoms. They also imply that doliolids, and most likely salps (also shown by Andersen 1986), would to some extent depend on soft-walled species such as flagellates, dinoflagellates and ciliates as suppliers of organic matter.

The large size of doliolid pellets suggests that few organisms in the neritic waters could ingest them. Besides doliolids and salps Thalia democratica, the calanoid copepods Temora stylifera and T. turbinata, due to their raptorial feeding behavior and abundance, would be able to utilize the Dolioletta gegenbauri pellets. Furthermore, the poecilostomatoid copepod genus Oncaea, known to feed on aggregates and occurring abundantly on continental shelves (Paffenhöfer 1983), could thrive on such pellets. Doliolids are known to ingest and appear to utilize (assimilate/digest) their own fecal pellets (G.-A. Paffenhöfer unpubl. data). What could be the nutritional value of such fecal pellets to other metazooplankton? While copepod pellets do not appear to support the growth of other copepods (e.g. Paffenhöfer \& Knowles 1979) as they no longer possess essential polyunsaturated fatty acids (e.g. Müller-Navarra 1995), pellets from doliolids, because of their incomplete digestion, could still contain a certain percentage of such fatty acids, and could therefore support the growth of various feeders including those of the benthos.

The C:N values of fecal pellets from the 4 experimental series ranged from 5.7 (Dolioletta gegenbauri and Thalassiosira weissflogii) to 7.7 (D. gegenbauri and Rhizosolenia alata), while those originating from Eucalanus hyalinus were slightly higher than those of the different food species (Table 1). The copepods appeared to have removed nitrogen at a higher rate than carbon as the $\mathrm{C}: \mathrm{N}$ ratio of $T$. weissflogii was 5.5. For the doliolids, the low value of 5.7 of pellets originating from T. weissflogii was close to the C:N ratio of $T$. weissflogii, and could be indicative of limited digestion, as shown for pellets as a percentage of ingestion (Table 1). The ratio of 7.7 of pellets originating from the ingestion of $R$. alata could imply that the doliolids were able to extract more nitrogen than carbon from $R$. alata, whose C:N ratio was 6.0. The C:N ratios of doliolid pellets could have been somewhat affected by the mucous net produced by these animals to collect their food. This net is ingested together with their food, and therefore should contribute to each fecal pellet. The C:N ratios of pellets from our copepod experiments were close to or lower than those from previous copepod studies (Table 3). The cited copepod pellet C:N data vary considerably and should partly be a function of food abundance, type of food and collection time after release. The salp pellet $\mathrm{C}: \mathrm{N}$ data originated from natural food in the California Current (Bruland \& Silver 1981) and the open subtropical ocean (Madin 1982, Caron et al. 1989). Since particles in the nanoplankton range from the warm open ocean are mostly soft-walled with concentrations usually much lower than in neritic waters (e.g. Caron et al.1995), their digestion should be rather effective, resulting in the removal of most nitrogenous contents from food particles and high $\mathrm{C}: \mathrm{N}$ ratios. The $\mathrm{C}: \mathrm{N}$ data of Bruland \& Silver (1981) and of our study are far lower than those from warm subtropical regions (Table 3). The California Current might have carried a far higher concentration of phytoplankton since the salp pellets were densely packed, which would have resulted in less efficient digestion than in the phytoplanktondilute Sargasso Sea. 
Could doliolid pellets with such high carbon and nitrogen content be encountered in nature? High diatom concentrations were repeatedly encountered in upwellings on the southeastern shelf of the USA during summer, as were high concentrations of doliolids in different seasons including summer. Single cells of Thalassiosia sp., $8 \mu \mathrm{m}$ in cell width, reached concentrations of $0.5 \mathrm{~mm}^{3}$ of cell volumes $\mathrm{l}^{-1}$ (Paffenhöfer 1983), and large diatoms, 65 to $110 \mu \mathrm{m}$ in cell width, reached 5 to $7 \mathrm{~mm}^{3}$ of cell volumes $\mathrm{l}^{-1}$ (Paffenhöfer \& Lee 1987b). Concentrations of Dolioletta gegenbauri often surpassed 1000 zooids m ${ }^{-3}$ (e.g. Deibel 1985, Paffenhöfer \& Lee 1987a, Paffenhöfer et al. 1995). At these concentrations of doliolids and diatoms, not only large amounts of pellets would be produced but also large amounts of utilizable particulate carbon and nitrogen would contribute to the vertical flux (e.g. Bruland \& Silver 1981, Michaels \& Silver 1988). This would mainly occur in neritic waters where doliolids and diatoms have been found at high concentrations (Paffenhöfer et al. 1995 and references therein). This could also happen in ocean margin waters, which are regularly occupied by particle-laden eddies (e.g. Lee et al. 1991) in which these thaliaceans have been found at low abundances.

\section{CONCLUSIONS}

Our observations revealed differences in the digestion performance of calanoids and doliolids offered a diet of diatoms. They also revealed differences in doliolid digestion of small versus large diatoms; small diatoms were hardly digested. This has implications for both the doliolids and the benthic communities. The doliolids cannot extract much energy from small diatoms, and therefore would have to rely to some extent on soft-bodied cells and large diatoms as a food source; continental shelf benthic communities could receive particulate organic matter from the partly digested doliolid fecal pellets.

Acknowledgements. This research was supported by NSF Grant OCE 9633401 (On the significance of doliolids as consumers and producers). Dr. D. Deibel evaluated an earlier version of this manuscript; Dr. P. Kremer and 2 anonymous referees provided constructive comments. The captain and crew of the RV 'Savannah' contributed to our studies with their professional attitude. The authors would like to express their gratitude to all who supported their endeavor.

\section{LITERATURE CITED}

Andersen V (1986) Effect of temperature on the filtration rate and percentage assimilation of Salpa fusiformis Cuvier (Tunicata: Thaliacea). Hydrobiologia 137:135-140

Belousov IM, Ivanov YA, Paternak T, Rass TS, Rossov VV
(1966) Oceanographic research by the Soviet-Cuban marine expedition. Oceanology (USSR) 6:312-320

Binet D (1976) Contribution a l'écologie de quelques taxons du zooplankton de Côte d'Ivoîre. II. Dolioles-SalpesAppendiculaires. Doc Scien Centre Rech Oceanogr Abidjan 7:45-61

Bruland KW, Silver MW (1981) Sinking rates of fecal pellets from gelatinous zooplankton (salps, pteropods, doliolids). Mar Biol 63:295-300

Caron DA, Madin LP, Cole JJ (1989) Composition and degradation of salp fecal pellets: implications for vertical flux in oceanic environments. J Mar Res 47:829-850

Caron DA, Dam HG, Kremer P, Lessard EJ and 6 others (1995) The contribution of microorganisms to particulate carbon and nitrogen in surface waters of the Sargasso Sea near Bermuda. Deep-Sea Res I 42:943-972

Conover RJ (1966) Assimilation of organic matter by zooplankton. Limnol Oceanogr 11:338-345

Conover RJ (1978) Transformation of organic matter. In: Kinne O (ed) Marine ecology, Vol 4. John Wiley \& Sons, New York, p 221-499

Conover WJ (1984) Practical nonparametric statistics. John Wiley \& Sons, New York

Conover RJ, Lalli CM (1974) Feeding and growth in Clione limacine (Phipps), a pteropod mollusc. II. Assimilation, metabolism, and growth efficiency. J Exp Mar Biol Ecol 16:131-154

Corner EDS (1961) On the nutrition and metabolism of zooplankton. I. Preliminary observations on the feeding of the marine copepod, Calanus finmarchicus (Claus). J Mar Biol Assoc UK 41:5-16

Corner EDS, Head RN, Kilvington CC (1972) On the nutrition and metabolism of zooplankton. VIII. The grazing of Biddulphia cells by Calanus helgolandicus. J Mar Biol Assoc UK 52:847-861

Cowie GL, Hedges JI (1996) Digestion and alteration of the biochemical constituents of a diatom (Thalassiosira weissflogii) ingested by an herbivorous zooplankton (Calanus pacificus). Limnol Oceanogr 41:581-594

Cowles TJ, Roman MR, Gauzens AL, Copley NJ (1987) Shortterm changes in the biology of a warm-core ring: zooplankton biomass and grazing. Limnol Oceanogr 32: 653-664

De Decker A (1973) Agulhas Bank plankton. In: Zeitzschel B (ed) The biology of the Indian Ocean. Springer-Verlag, New York, p 189-220

Deibel D (1985) Blooms of the pelagic tunicate, Dolioletta gegenbauri: are they associated with Gulf Stream frontal eddies? J Mar Res 43:211-236

Esnal GB, Simone LC (1982) Doliolidos (Tunicata, Thaliacea) del Golfo de Mexico y Mar Caribe. Physis (Buenos Aires) Secc A 40:51-57

Gibson DM, Paffenhöfer GA (2000) Feeding and growth rates of the doliolid, Dolioletta gegenbauri Uljanin (Tunicata, Thaliacea). J Plankton Res 22:1485-1500

He D, Yang G, Fang S, Shen W, Liu H, Gao A, Huang S (1988) Study of zooplankton ecology in Zhejiang coastal upwelling system - zooplankton biomass and abundance of major groups. Acta Oceanol Sin 7:607-620

Heron AC (1972) Population ecology of a colonizing species: the pelagic tunicate Thalia democratica. II. Population growth rate. Oecologia 10:294-312

Koga F (1986) The occurrence and production of zooplankton in Suo-mada, Western Seto Inland Sea. Bull Nansei Reg Fish Res Lab No 20:91-113

Köster M, Dahlke S, Meyer-Reil LA (1997) Microbiological studies along a gradient of eutrophication in a shallow 
coastal inlet in the Southern Baltic Sea (Nordrügensche Bodden). Mar Ecol Prog Ser 152:27-39

LeBorgne R (1983) Note sur les proliferations de Thaliaces dans le Golfe de Guinee. Oceanogr Trop 18:49-54

Lee TN, Yoder JA, Atkinson LP (1991) Gulf Stream frontal eddy influence on productivity of the southeast U.S. continental shelf. J Geophys Res 96:22191-22205

Madhupratap M, Devassy VP, Sreekumaran Nair SR, Rao TSS (1980) Swarming of pelagic tunicates associated with phytoplankton bloom in the Bay of Bengal. Ind J Mar Sci 9:69-71

Madin LP (1982) Production, composition and sedimentation of salp fecal pellets in oceanic waters. Mar Biol 67:39-45

Michaels AF, Silver MW (1988) Primary production, sinking fluxes and the microbial food web. Deep-Sea Res 35: 473-490

Møller EF, Thor P, Nielsen TG (2003) Production of DOC by Calanus finmarchicus, C. glacialis and C. hyperboreus through sloppy feeding and leakage from fecal pellets. Mar Ecol Prog Ser 262:185-191

Monteiro WM, Mureb MA, Valentin J (1975) O plancton na ressurgencia de Cabo Frio (Brasil). IV. Zooplancton. Primeiras consideracoes sobre a composicao e abundancia dos principais grupos. Publicacao do Instituto de Pesquisas da Marinha No. 85, Rio de Janeiro, p 1-9

Morales CE (1987) Carbon and nitrogen content of copepod fecal pellets: effect of food concentration and feeding behavior. Mar Ecol Prog Ser 36:107-114

Müller-Navarra D (1995) Evidence that a highly unsaturated fatty acid limits Daphnia growth in nature. Arch Hydrobiol 132:297-307

Paffenhöfer GA (1970) Cultivation of Calanus helgolandicus under controlled conditions. Helgol Wiss Meeresunters 20:346-359

Paffenhöfer GA (1983) Vertical zooplankton distribution on

Editorial responsibility: Barry \& Evelyn Sherr (Contributing Editors), Corvallis, Oregon, USA the northeastern Florida shelf and its relation to temperature and food abundance. J Plankton Res 5:15-33

Paffenhöfer GA, Knowles SC (1979) Ecological implications of fecal pellet size, production and consumption by copepods. J Mar Res 37:35-49

Paffenhöfer GA, Lee TN (1987a) Development and persistence of patches of thaliacea. S Afr J Mar Sci 5:305-318

Paffenhöfer GA, Lee TN (1987b) Summer upwelling on the southeastern continental shelf of the USA during 1981: distribution and abundance of particulate matter. Prog Oceanogr 19:373-401

Paffenhöfer GA, Mazzocchi MG (2003) Vertical distribution of subtropical epiplanktonic copepods. J Plankton Res 25: 1139-1156

Paffenhöfer GA, Atkinson LP, Lee TN, Verity PG, Bulluck LR III (1995) Distribution and abundance of thaliaceans and copepods off the southeastern USA during winter. Cont Shelf Res 15:255-280

Pieper RE, Holliday DV (1984) Acoustic measurements of zooplankton distributions in the sea. J Cons Int Explor Mer 41: 226-238

Pomeroy LR, Deibel D (1980) Aggregation of organic matter by pelagic tunicates. Limnol Oceanogr 25:643-652

Price HJ, Paffenhöfer GA (1985) Perception of food availability by calanoid copepods. Arch Hydrobiol Beih Ergebn Limnol 21:115-124

Price HJ, Paffenhöfer GA (1986) Effect of concentration on the feeding of a marine copepod in algal monocultures and mixtures. J Plankton Res 8:119-128

Price HJ, Paffenhöfer GA, Strickler JR (1983) Modes of cell capture in calanoid copepods. Limnol Oceanogr 28:116-123

Thor P, Dam HG, Rogers DR (2003) Fate of organic carbon released from decomposing copepod fecal pellets in relation to bacterial production and ectoenzymatic activity. Aquat Microb Ecol 33:279-288

Submitted: October 27, 2004; Accepted: February 17, 2005 Proofs received from author(s): June 20, 2005 